\title{
Antitumor effects and the underlying mechanism of licochalcone A combined with 5-fluorouracil in gastric cancer cells
}

\author{
XIAOLIN LIN ${ }^{1}$, LEI TIAN ${ }^{1}$, LISHA WANG ${ }^{2}$, WENYAN LI $^{3}$, QI XU ${ }^{1}$ and XIUYING XIAO ${ }^{1}$ \\ ${ }^{1}$ Department of Oncology, Ren Ji Hospital, School of Medicine, Shanghai Jiao Tong University, \\ Shanghai 200127; ${ }^{2}$ Department of Pathology, Fudan University Shanghai Cancer Center, Shanghai 200032; \\ ${ }^{3}$ Department of Oncology, Shanghai Xuhui Centre Hospital, Shanghai 200031, P.R. China
}

Received October 22, 2015; Accepted November 1, 2016

DOI: $10.3892 / \mathrm{ol} .2017 .5614$

\begin{abstract}
Licochalcone A (LCA) is a flavonoid extracted from licorice root that has antiparasitic, antibacterial and antitumor properties. Previous studies have revealed that LCA may be a novel treatment for gastric cancer. The present study further assessed the potential antitumor effects of LCA alone or in combination with 5-fluorouracil (5-FU), and the underlying mechanisms responsible for those effects in gastric cancer cells. The effects of LCA alone or in combination with 5-FU on SGC7901 and MKN-45 gastric cancer cell lines were studied using Cell Counting Kit-8, cell cycle, apoptosis and western blot analyses of cell check points and apoptosis-associated proteins. The results revealed that LCA inhibited cell proliferation, blocked cell cycle progression at the $\mathrm{G}_{2} / \mathrm{M}$ transition and induced apoptosis. Western blot analysis demonstrated that LCA treatment increased the levels of tumor proteins 21 and 27, as well as mouse double minute 2 homolog in gastric cancer cells. In addition, LCA treatment increased the expression levels of Bax, cleaved-poly ADP ribose polymerase, tumor protein 53 and caspase 3, and decreased the expression levels of Bcl-2. Therefore, the present study demonstrated that LCA alone or in combination with 5-FU may have significant anticancer effects on gastric cancer cells, and may be a novel therapeutic for the treatment of gastric cancer in the future.
\end{abstract}

\section{Introduction}

Gastric cancer is the fourth most frequently diagnosed cancer and the second leading cause of cancer-associated mortality worldwide $(1,2)$. Despite recent advances in adjuvant and neo-adjuvant therapy and improved understanding of gastric

Correspondence to: Mrs. Xiuying Xiao, Department of Oncology, Ren Ji Hospital, School of Medicine, Shanghai Jiao Tong University, 160 Pujian Road, Shanghai 200127, P.R. China

E-mail: xiaoxiuying2002@163.com

Key words: licochalcone A, gastric cancer, cell viability, apoptosis, cell cycle cancer biology, progress in the treatment of gastric cancer has been limited. Gastric cancer has a high recurrence rate and $>50 \%$ of patients succumb to this disease within 3 years of diagnosis (3), highlighting the requirement for novel treatment regimens (4).

The use of natural products in gastric cancer therapy has been the focus of a number of studies (5-9); licorice is a traditional herbal medicine that originates from the licorice root, and is one of the most commonly prescribed herbs in China for the treatment of various diseases, including microbial infections and cancer $(10,11)$. Licochalcone A ( LCA; $\mathrm{C}_{21} \mathrm{H}_{22} \mathrm{O}_{4}$; molecular weight, 338.4$)$ is the primary active compound in the licorice species Glycyrrhiza glabra and is an estrogenic flavonoid with antiparasitic, antibacterial and antitumor properties (12-14). It has been demonstrated previously that LCA is the most cytotoxic licorice compound, and is able to inhibit the growth of gastric cancer cells by arresting cell cycle progression and inducing apoptosis (15). The current standard chemotherapeutic regimen for gastric cancer is 5-fluorouracil (5-FU)-based combined chemotherapy, and various herbal extracts are widely used for the treatment of gastric cancer, including paclitaxel and curcumin $(16,17)$. In addition, in cases where a novel therapeutic is used for the treatment of gastric cancer, 5-FU is frequently used as a combination therapy (18). In the present study, the inhibitory effects of LCA on gastric cancer cells alone and in combination with 5-FU were evaluated.

\section{Materials and methods}

Cell culture and reagents. The SGC7901 (moderately differentiated) and MKN-45 (poorly differentiated) human gastric cancer cell lines were purchased from the American Type Culture Collection (Manassas, VA, USA) and cultured in RPMI-1640 (Thermo Fisher Scientific, Inc., Waltham, MA, USA) supplemented with $10 \%$ fetal bovine serum (FBS; Thermo Fisher Scientific, Inc), $1 \%$ Gibco $^{\circledR}$ Glutamax $^{\mathrm{TM}}$ (Thermo Fisher Scientific, Inc.) and 1\% penicillin and streptomycin, and maintained in an incubator at $37^{\circ} \mathrm{C}$ with a humidified atmosphere containing $5 \% \mathrm{CO}_{2}$.

Cell proliferation assay. SGC7901 and MKN-45 cells were seeded in 96-well plates at a density of 1,000 cells/well 
with $100 \mu \mathrm{l}$ complete culture medium. Following adhesion for $24 \mathrm{~h}$, cells were treated with LCA (Phytomarker Ltd., Tianjin, China) or LCA plus 5-FU (Shanghai Xudong Haipu Pharmaceutical Co., Ltd., Shanghai, China) at various concentrations (diluted to $15.625,31.25,62.5,125$ and $187.5 \mu \mathrm{g} / \mathrm{ml}$ in complete medium). In a previous study (15), the selected concentration of LCA was $25 \mu \mathrm{M}$. Cells that were not exposed to LCA or 5-FU were used as negative controls (blank). Following LCA or LCA plus 5-FU treatment, the supernatant was removed, $100 \mu \mathrm{l}$ RPMI-1640 medium containing $10 \mu \mathrm{l}$ Cell Counting Kit-8 (CCK8; Dojindo Molecular Technologies, Inc., Kumamoto, Japan) was added to each well and the cells were incubated at $37^{\circ} \mathrm{C}$ for $3 \mathrm{~h}$. The culture plates were then agitated for $10 \mathrm{~min}$ at room temperature $20^{\circ} \mathrm{C}$ and optical density (OD) values were read at $450 \mathrm{~nm}$ using a microplate reader (SpectraMax 190; Molecular Devices, LLC, Sunnyvale, CA, USA).

Cell cycle analysis. Cells $\left(3 \times 10^{5}\right)$ were plated in RPMI-1640 medium and then treated with $25 \mu \mathrm{M}$ LCA and $15.625 \mu \mathrm{g} / \mathrm{ml}$ LCA plus 5-FU. The cells were harvested at 0 and $48 \mathrm{~h}$, suspended in $300 \mu \mathrm{l}$ PBS, mixed with cold ethanol (700 $\mu \mathrm{l}$ ) and incubated at $4^{\circ} \mathrm{C}$ overnight. Following centrifugation at $4^{\circ} \mathrm{C} 1,000 \times g$ for $5 \mathrm{~min}$, the pellet was washed with cold PBS, resuspended in $500 \mu \mathrm{l}$ PBS and incubated with $50 \mu \mathrm{l}$ RNase (final concentration, $20 \mu \mathrm{g} / \mathrm{ml}$ ) at $4^{\circ} \mathrm{C}$ for $30 \mathrm{~min}$. Subsequently, the cells were incubated with propidium iodide (final concentration, $50 \mu \mathrm{g} / \mathrm{ml}$ ) at $4^{\circ} \mathrm{C}$ for $30 \mathrm{~min}$ in the dark. The cell cycle distribution was then determined using a FACSAria Flow Cytometer (BD Biosciences, Franklin Lakes, NJ, USA).

Apoptosis analysis. LCA and LCA plus 5-FU-induced apoptosis in SGC7901 and MKN-45 cells was determined using flow cytometry with the Annexin V-fluorescein isothiocyanate (FITC) Apoptosis Detection kit (BioVision, Inc., Milpitas, CA, USA) according to the manufacturer's protocol. Briefly, $3 \times 10^{5}$ cells were plated and treated with $25 \mu \mathrm{M}$ LCA or $15.625 \mu \mathrm{g} / \mathrm{ml} \mathrm{LCA}$ plus 5-FU for 24, 48 and $72 \mathrm{~h}$. To prepare for staining analysis, cells were harvested, washed in PBS and incubated with Annexin $\mathrm{V}$ and propidium iodide in binding buffer at room temperature for $10 \mathrm{~min}$ in the dark. The stained cells were analyzed using a FACSAria flow cytometer.

Western blot analysis. SGC7901 and MKN-45 whole cell lysates were produced using radioimmunoprecipitation assay buffer (Beyotime Institute of Biotechnology, Shanghai, China) to lyse the cells, followed by centrifugation at $4{ }^{\circ} \mathrm{C}$ and $12,000 \times \mathrm{g}$ for $5 \mathrm{~min}$ and collection of the supernatant fraction for immunoblotting. The proteins $(50 \mu \mathrm{g})$ were separated using 5-10\% SDS-PAGE and transferred onto a nitrocellulose membrane. Following blocking with 5\% nonfat milk in blocking buffer $(20 \mathrm{mM}$ Tris-buffered saline containing $0.1 \%$ Tween-20; pH 7.5), the membranes were incubated with primary antibody at $4^{\circ} \mathrm{C}$ overnight and then incubated at room temperature for $1 \mathrm{~h}$ with the appropriate horseradish peroxidase-conjugated secondary antibody. The primary antibodies were anti-B-cell-lymphoma-2 (Bcl-2; \#ab7973; Abcam, Cambridge, UK), anti-Bcl-2-associated $\mathrm{X}$ protein (Bax; \#2772; Cell Signaling Technology, Inc., Danvers, MA,
USA), anti-caspase 3 (\#ab44976; Abcam), anti-poly ADP ribose polymerase (PARP; \#AP102-1; Beyotime Institute of Biotechnology), anti-tumor protein (p)53 (\#op43T; Merck Millipore, Darmstadt, Germany), anti-p27 (\#2747-1; Epitomics, Burlingame, CA, USA), anti-p21 (\#ab109520; Abcam), anti-mouse double minute 2 homolog (MDM2; \#ab16895, Abcam) and anti-GAPDH (\#AP0063; Bioworld Technology Inc., St. Louis Park, MN, USA). GAPDH antibodies were diluted to 1:5,000 in blocking solution. The dilutions for all other primary antibodies were as follows: Caspase 3 (dilution, 1:1,000), Bcl-2, Bax, p21, p27, p53, PARP (dilution, 1:500) and MDM2 (dilution, 1:50). The secondary antibodies included horseradish peroxidase-linked anti-mouse immunoglobulin $\mathrm{G}$ (dilution, 1:5,000; sc-358914) and anti-rabbit immunoglobulin G (dilution, 1:4,000; sc-2357) (Santa Cruz Biotechnology, Inc., Dallas, TX, USA) at room temperature for $1 \mathrm{~h}$. The immunoreactive bands were visualized using the Enhanced Chemiluminescence plus Western Blotting Detection system, which was purchased from Bio-Rad Laboratories, Inc. (Hercules, CA, USA). GAPDH was used as a loading control for each sample.

Statistical analysis. The experimental data were all expressed as the mean \pm standard deviation, and statistical differences between groups were evaluated with a two-tailed Student's $t$-test using SPSS version 13 (SPSS, Inc., Chicago, IL, USA). $\mathrm{P}<0.05$ was considered to indicate a statistically significant difference.

\section{Results}

LCA induces inhibition of gastric cancer cell proliferation. The cytotoxicity of LCA and LCA plus 5-FU against the SGC7901 and MKN-45 gastric cancer cell lines was evaluated. Cell proliferation was observed at 24, 48 and $72 \mathrm{~h}$ following treatment. MKN45 cells were moderately sensitive to 5-FU, and SGC7901 cells were relatively resistant to 5-FU. Therefore, the most appropriate concentration of 5-FU was determined as $15.625 \mu \mathrm{g} / \mathrm{ml}$. Fig. 1 presents the relative OD values of SGC-7901 and MKN-45 cells following exposure to the blank (BL; negative control), LCA and LCA plus 5-FU. Compared with the control group, cancer cell proliferation was significantly inhibited by LCA alone (SGC7901, $\mathrm{P}=0.011 ; \mathrm{MKN}-45, \mathrm{P}=0.016)$ and LCA in combination with 5-FU (SGC7901, $\mathrm{P}=0.004$; MKN-45, $\mathrm{P}=0.029$ ). This inhibitory effect was more pronounced in the combination group, compared with LCA alone (Fig. 1).

LCA-induces $G_{2} / M$ phase arrest and 5-FU induces $G_{0} / G_{1}$ phase arrest in human gastric cancer cells. The results from a previous study revealed that LCA may induce $G_{2} / M$ phase arrest by affecting the levels of cyclin A, cyclin B, retinoblastoma and MDM2 (9). The present study further examined the effects of LCA alone or in combination with 5-FU on the cell cycle distribution of gastric cancer cells. The cell cycle distribution of the cells following exposure to LCA or LCA plus 5-FU for $48 \mathrm{~h}$ is presented in Table I. The SGC-7901 cells treated with LCA exhibited significant $\mathrm{G}_{2} / \mathrm{M}$ phase arrest compared with the cells treated with LCA plus 5-FU $(27.04 \pm 0.81$ vs. $16.25 \pm 0.90 \%$, respectively; $\mathrm{P}<0.001$; Fig. $2 \mathrm{~A})$ 
Table I. Cell cycle distribution of SGC-7901 and MKN-45 human gastric cancer cells following exposure to LCA or LCA plus 5-FU for $48 \mathrm{~h}$.

\begin{tabular}{lcccc}
\hline Cell line & Cell cycle stage & BL, (mean \pm SD $) \%$ & LCA, (mean \pm SD $) \%$ & LCA $+5-F U,($ mean \pm SD $) \%$ \\
\hline SGC-7901 & $\mathrm{G}_{0} / \mathrm{G}_{1}$ & $37.66 \pm 0.46$ & $26.32 \pm 0.77$ & $67.67 \pm 0.77$ \\
& $\mathrm{~S}$ & $42.47 \pm 0.63$ & $46.65 \pm 0.57$ & $16.08 \pm 0.51$ \\
& $\mathrm{G}_{2} / \mathrm{M}$ & $19.87 \pm 0.23$ & $27.04 \pm 0.81$ & $16.25 \pm 0.90$ \\
MKN-45 & $\mathrm{G}_{0} / \mathrm{G}_{1}$ & $63.21 \pm 0.84$ & $68.12 \pm 0.94$ & $50.60 \pm 1.62$ \\
& $\mathrm{~S}$ & $25.58 \pm 1.43$ & $19.31 \pm 0.34$ & $45.61 \pm 1.88$ \\
& $\mathrm{G}_{2} / \mathrm{M}$ & $11.21 \pm 0.68$ & $12.58 \pm 0.77$ & $3.79 \pm 0.33$ \\
\hline
\end{tabular}

BL, blank control; LCA, licochalcone A; 5-FU, 5-fluorouracil; SD, standard deviation.
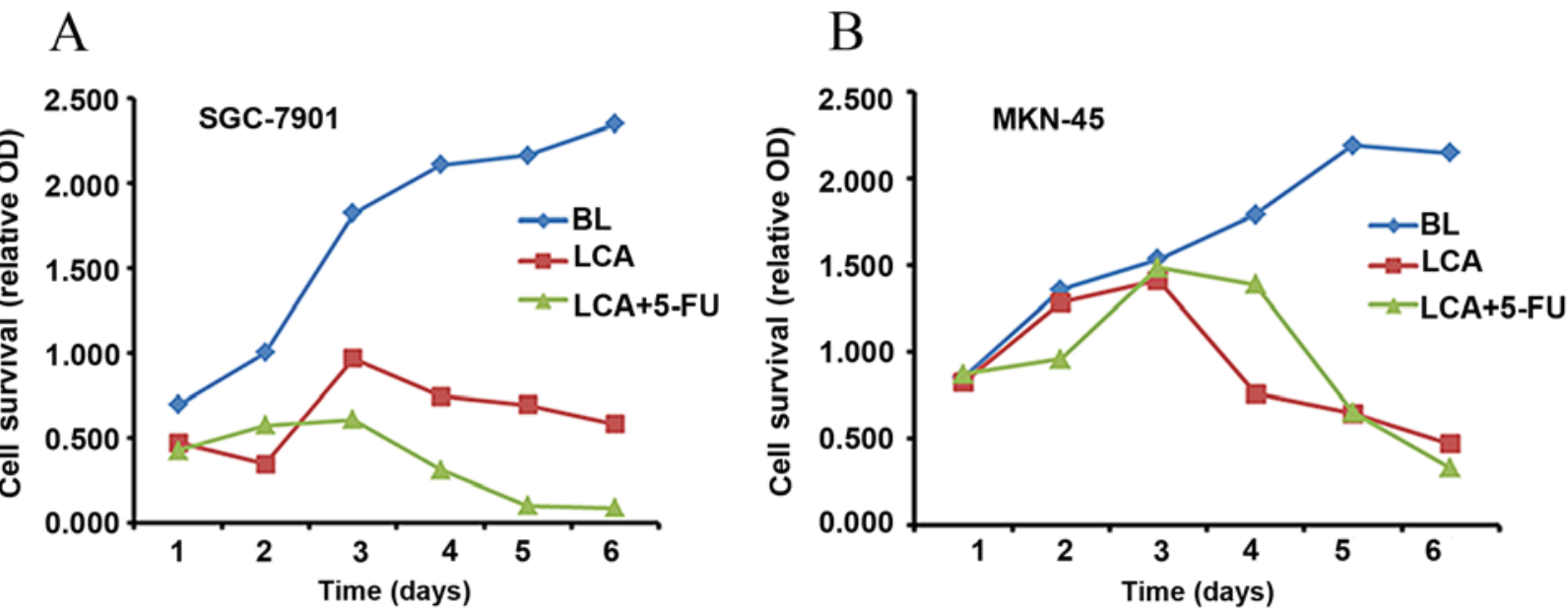

Figure 1. Cytotoxicity of LCA or/and 5-FU in the (A) SGC-7901 and (B) MKN-45 gastric cancer cell lines. Cytotoxicity was assessed using a cell-counting kit-8 assay at 1, 2, 3, 4, 5 and 6 days after treatment. All assays were performed in triplicate. BL, blank control; LCA, licochalcone A; 5-FU, 5-fluorouracil; OD, optical density.

or the blank cells $(27.04 \pm 0.81$ vs. $19.87 \pm 0.23 \%$, respectively; $\mathrm{P}<0.001)$. A higher proportion of the SGC7901 cells treated with LCA plus 5-FU exhibited $\mathrm{G}_{0} / \mathrm{G}_{1}$ arrest compared with the blank cells $(67.67 \pm 0.77$ vs. $37.66 \pm 0.46 \%$, respectively; $\mathrm{P}<0.001)$ or LCA alone $(67.67 \pm 0.77$ vs. $26.32 \pm 0.77 \%$, respectively; $\mathrm{P}<0.001) . \mathrm{G}_{2} / \mathrm{M}$ phase arrest was also observed in the MKN-45 cells treated with LCA and with LCA and 5-FU in combination $(12.58 \pm 0.77$ vs. $3.79 \pm 0.33 \%$, respectively; $\mathrm{P}<0.001$; Fig. 2B) for $48 \mathrm{~h}$. The MKN-45 cells treated with LCA also exhibited increased $\mathrm{G}_{2} / \mathrm{M}$ arrest compared with the blank cells ( $12.58 \pm 0.77$ vs. $11.21 \pm 0.68 \%$, respectively); however, this result was not statistically significant $(\mathrm{P}=0.084)$. By contrast, the MKN-45 cells treated with LCA plus 5-FU exhibited a significantly lower frequency of $\mathrm{G}_{0} / \mathrm{G}_{1}$ arrest compared with the blank cells $(50.60 \pm 1.62$ vs. $63.21 \pm 0.84 \%$, respectively; $\mathrm{P}<0.001)$ or LCA alone $(50.60 \pm 1.62$ vs. $68.12 \pm 0.94 \%$, respectively; $\mathrm{P}<0.001)$. Fig. 2C-E present the cell cycle distribution of the SGC7901 cells following exposure to the blank (Fig. 2C), LCA (Fig. 2D) and LCA combined with 5-FU (Fig. 2E). These data suggest that LCA-induced growth inhibition in gastric cancer cells may be associated with the induction of $\mathrm{G}_{2} / \mathrm{M}$ arrest in the two gastric cancer lines, whereas 5-FU inhibited cell proliferation by inducing cell cycle arrest during the $\mathrm{G}_{0} / \mathrm{G}_{1}$ phase in the moderately differentiated SGC-7901 cells. This result is concordant with a previous study, which demonstrated that 5-FU was able to induce $\mathrm{G}_{0} / \mathrm{G}_{1}$ arrest in tumor cells (19).

LCA and its combination with 5-FU induces apoptosis in human gastric cancer cells. To determine whether LCA is able to inhibit growth in gastric cancer cells by inducing apoptosis, SGC7901 and MKN-45 cells were treated with LCA $(25 \mu \mathrm{M})$ and LCA plus 5-FU $(15.625 \mu \mathrm{g} / \mathrm{ml})$ as aforementioned. Apoptotic cell numbers were assessed using an Annexin V-FITC Apoptosis Detection kit. The results revealed that exposure of MKN-45 cells to LCA resulted in a significant increase of apoptotic cells in a time-dependent manner $(13.27 \pm 0.24 \%$ apoptotic cells at $24 \mathrm{~h}, 17.21 \pm 0.65 \%$ at $48 \mathrm{~h}$ and $18.16 \pm 0.22 \%$ at $72 \mathrm{~h}$; $\mathrm{P}<0.001)$. The exposure of MKN-45 cells to LCA plus 5-FU also significantly increased the number of apoptotic cells over time $(14.88 \pm 0.39 \%$ apoptotic cells at $24 \mathrm{~h}, 22.62 \pm 0.13 \%$ at $48 \mathrm{~h}$ and $42.55 \pm 0.72 \%$ at $72 \mathrm{~h} ; \mathrm{P}<0.001$ ), and more apoptotic cells were detected when the MKN-45 cells were exposed to LCA plus 5-FU as compared with LCA treatment alone (Fig. 3A). The SGC-7901 cells also exhibited dose-dependent apoptosis when exposed to LCA or LCA plus 5-FU; however, this varied from the results observed in MKN-45 cells. SGC-7901 cells 

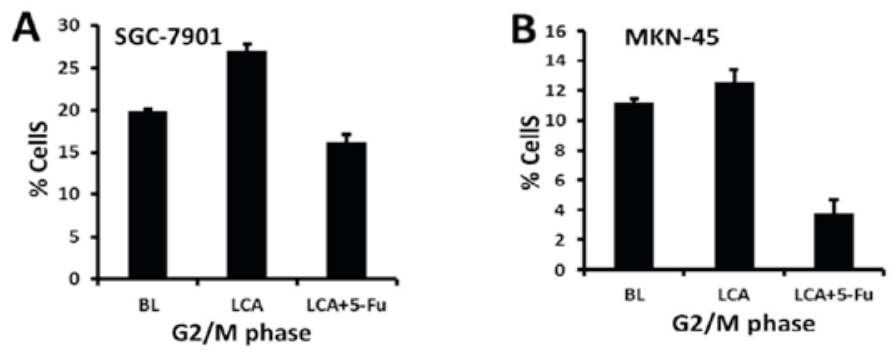

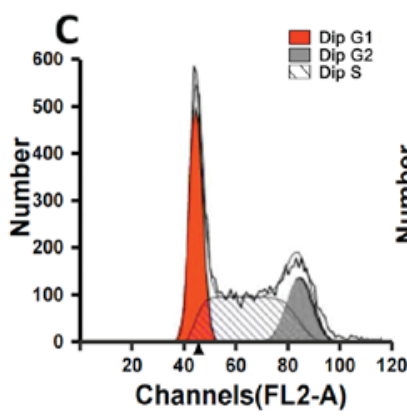

$\mathrm{BL}$

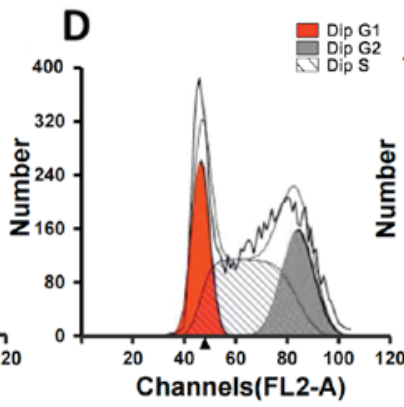

LCA

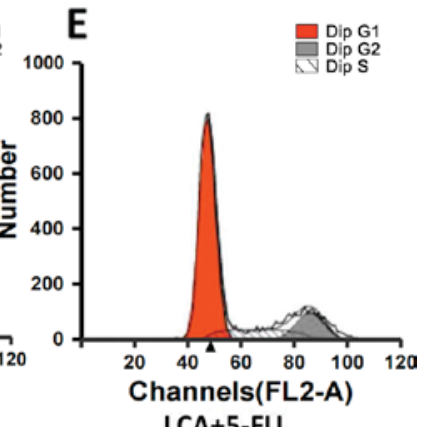

LCA+5-FU

Figure 2. Effects of LCA on the cell cycle progression of gastric cancer cells. (A) SGC-7901 and (B) MKN-45 cell lines were exposed to BL, LCA and LCA combined with 5-FU for $48 \mathrm{~h}$. The cell cycle distributions of SGC7901 cells when exposed to (C) blank control, (D) LCA (which induced growth inhibition associated with $\mathrm{G} 2 / \mathrm{M}$ arrest) and (E) LCA combined with 5-FU (which induced $\mathrm{G}_{0} / \mathrm{G}_{1}$ arrest more markedly) for $48 \mathrm{~h}$ are presented. All assays were performed in triplicate. BL, blank control; LCA, licochalcone A; 5-FU, 5-fluorouracil.
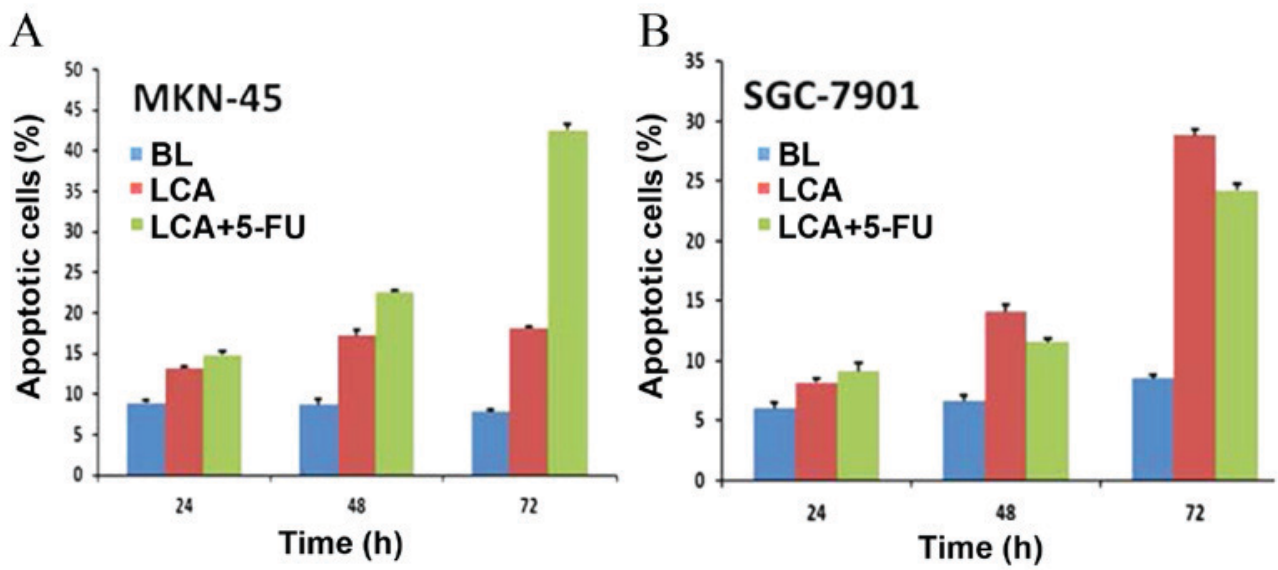

Figure 3. Induction of apoptosis in (A) MKN-45 and (B) SGC-7901 human gastric cancer cells following the administration of various treatments. Cells were exposed to BL, LCA and LCA plus 5-FU for 24, 48 and $72 \mathrm{~h}$. All assays were performed in triplicate. BL, blank control; LCA, licochalcone A; 5-FU, 5-fluorouracil.

exposed to LCA alone exhibited higher levels of apoptosis compared with those treated with LCA plus 5-FU at 48 and $72 \mathrm{~h}(14.07 \pm 0.56$ vs. $11.56 \pm 0.26 \%$ at $48 \mathrm{~h}, \mathrm{P}<0.001 ; 28.82 \pm 0.48$ vs. $24.23 \pm 0.51 \%$ at $72 \mathrm{~h}, \mathrm{P}<0.001$ ) (Fig. $3 \mathrm{~B}$ ). This may be due to the relative resistance of SGC7901 cells to 5-FU (20). The number of apoptotic cells was markedly higher in cell samples treated with LCA compared with the blank controls $(6 \pm 0.47$ vs. $8.19 \pm 0.30 \%$ apoptotic cells at $24 \mathrm{~h}, 6.62 \pm 0.47$ vs. $14.07 \pm 0.56 \%$ at $48 \mathrm{~h}$ and $8.52 \pm 0.24$ vs. $28.82 \pm 0.48 \%$ at $72 \mathrm{~h} ; \mathrm{P}<0.001)$. This effect was more pronounced in cell samples treated with LCA plus 5-FU, except for SGC-7901 cells, which were relatively resistant to 5-FU. These results indicated that LCA was able to effectively induce apoptosis in two gastric cancer cell lines and that combining LCA with 5-FU induced more apparent apoptosis.
Effects of LCA on the expression levels of apoptosis and cell cycle-associated proteins in gastric cancer cells. The Bcl-2 family proteins are important in the regulation of apoptosis (21). A previous study revealed that LCA induces a dose-dependent increase in the expression levels of Bax and a decrease in the levels of Bcl-2 (15). The current study further analyzed the levels of Bcl-2 and Bax in cells treated with blank control, LCA and LCA plus 5-FU. Exposure of the SGC-7901 cells to LCA resulted in a significant increase $(\mathrm{P}<0.001)$ in the expression levels of Bax protein and decreased levels of Bcl-2. A similar result was observed when SGC-7901 cells were exposed to LCA plus 5-FU, and the increase in Bax expression levels was more marked. The protein expression levels of Bax and Bcl-2 were similar to the blank control group following exposure to LCA or LCA plus 5-FU in the MKN-45 cells (Fig. 4). 


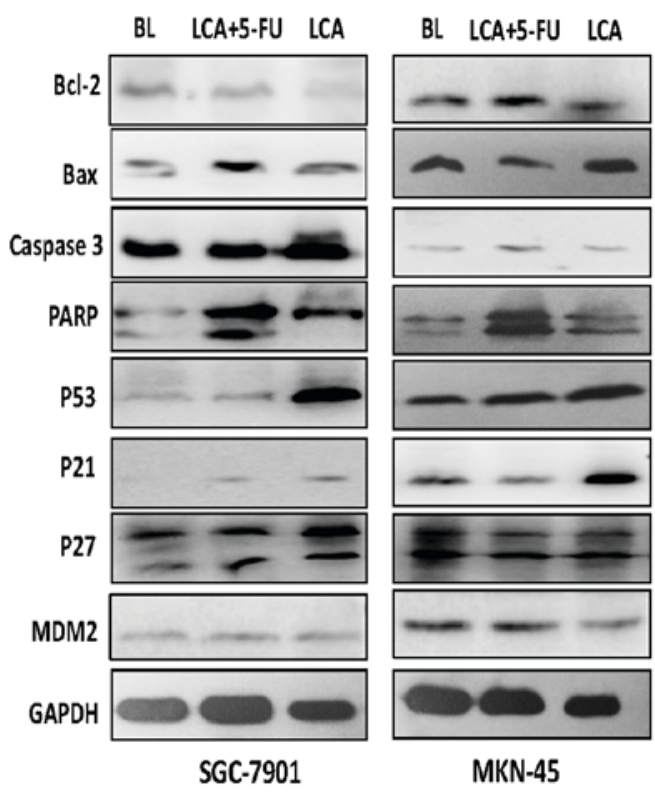

Figure 4. Expression levels of cell cycle-associated proteins were determined using western blot analysis following the treatment of SGC-7901 and MKN-45 human gastric cancer cells with BL, LCA and LCA plus 5-FU for 48 h. Bcl-2, B-cell lymphoma 2; Bax, B-cell lymphoma 2-associated $\mathrm{X}$ protein; PARP, poly ADP ribose polymerase; $\mathrm{p}$, tumor protein; MDM2, mouse double minute 2 homolog.

Caspase-3, an executioner caspase that is activated by caspase-9, cleaves a broad spectrum of cellular target proteins, including nuclear PARP, which leads to a cell-death cascade (22). To clarify the mechanism underlying the apoptotic signaling pathway activation mediated by LCA and 5-FU, the effects of LCA and LCA plus 5-FU on the activation of caspase-3 and PARP were examined. The gastric cancer cells that were exposed to LCA exhibited increased PARP cleavage. A trend of increased caspase-3 expression levels was observed in SGC-7901 cells, and to a lesser degree in MKN-45 cells. The increase of PARP and caspase 3 expression levels in gastric cancer cells that were exposed to LCA plus 5-FU was more marked compared with cells treated with LCA alone (Fig. 4). This suggests that the canonical mitochondrial apoptotic signaling pathway is activated by LCA and that 5-FU may enhance the effects of LCA.

As p21 and p27 are important in the regulation of the cell cycle (23), the effects of LCA and 5-FU on the expression levels of these proteins were examined. As presented in Fig. 4, treatment with LCA resulted in an increase in the expression levels of p21 protein in the SGC-7901 and MKN-45 gastric cancer cell lines. However, no statistically different change was observed in p27 expression levels following treatment with LCA, but there remained a trend of increase in SGC-7901 cells. These observations suggest that increased p21 and p27 expression levels be important for LCA-induced $\mathrm{G}_{2} / \mathrm{M}$ phase arrest in human gastric cancer cells. P53 and MDM2 also serve essential roles in the regulation of the cell cycle (23). Treatment with LCA alone or LCA plus 5-FU resulted in increased p53 protein expression levels (Fig. 4), suggesting that LCA may affect the levels of p53 in gastric cancer cells.

\section{Discussion}

The roots and rhizomes of licorice (Glycyrrhiza) species have been used globally as a natural sweetener and herbal medicine. Licorice root is a traditional medicine used primarily for the treatment of hepatitis $\mathrm{C}$, peptic ulcers, and pulmonary and skin diseases (24). LCA is a natural phenol licorice compound isolated from the roots of Glycyrrhiza with numerous biological functions, including anti-angiogenesis, antiparasitic, antioxidant, antibacterial and anti-inflammatory activities (25). In the current study, the anti-cancer effects of LCA alone and in combination with 5-FU on gastric cancer cells were evaluated.

Gastric cancer is an aggressive disease with a poor prognosis, even when the lesions are completely resected without distant metastasis (26). A meta-analysis of phase 2 and 3 randomized gastric cancer trials demonstrated that combination chemotherapy improves the overall survival rates compared with single-agent chemotherapy or best supportive care $(1,27)$. However, the resulting toxicity remained significant and the survival benefit was modest (4). Therefore, the potential use of natural products in the treatment of gastric cancer has been the focus of previous studies (5-9). In the present study, LCA was able to inhibit cell proliferation, block cell cycle progression at the $\mathrm{G}_{2} / \mathrm{M}$ transition and induce apoptosis in gastric cancer cells. Thus, LCA may be a potential novel therapeutic agent for gastric cancer. In addition, 5-FU induced $G_{0} / G_{1}$ arrest in gastric cancer lines and enhanced the effects of growth inhibition and apoptosis, and may therefore be used as a combination treatment.

The dysregulation of the cell cycle is correlated with the process of tumor development (28). Cyclin-dependent kinases (CDKs) are key regulators of the cell cycle (29). This process also involves positive and negative regulatory factors, including the cyclin dependent kinase inhibitors (CKIs) p21 and p27 (30). p53 is activated in response to DNA damage and activates p21, which binds to and inhibits several CDKs resulting in cell cycle arrest and the induction of apoptosis in invading tumors (31). p27 is activated by TGF- $\beta$ and also inhibits several CDKs, whereas MDM2 is a negative regulator of p53 and triggers cell cycle progression by reversing p53-mediated cell cycle arrest and apoptosis (32). Cyclins and CDKs are overexpressed and dysregulated in a variety of types of human cancer and p21 and p27 are frequently mutated and exhibit reduced expression levels (33). Human tumor formation often involves the deactivation of the tumor suppressor p53 and overexpression of the oncogene MDM2 (34,35). The present study demonstrated that LCA treatment was able to increase the levels of p21, p27 and p53 and decrease the levels of MDM2 in gastric cancer cells, an effect that was amplified by treatment with LCA in combination with 5-FU.

The impairment of apoptosis (programmed cell death) is important in the pathogenesis and progression of cancer, and is a major barrier to effective treatment (27). Apoptosis is regulated by members of the Bcl-2 family that function upstream of the interleukin-1 converting enzyme family of cysteine proteases, also termed caspases $(36,37)$. During the induction of apoptosis, caspase proteases are sequentially activated and subsequently cleave several cellular substrates, including PARP, a nuclear enzyme involved in DNA repair, maintenance 
of genome integrity and post-translational modification of protein ribosylation (38). The current study demonstrated that LCA treatment increased the levels of Bax, caspase 3 and cleaved-PARP and decreased the levels of Bcl-2 in gastric cancer cells. In addition, LCA may function synergistically with 5-FU.

In conclusion, the present study demonstrated that LCA exhibits antitumor activity in vitro by inhibiting cell proliferation, arresting cell cycle progression and inducing apoptosis in gastric cancer cells. 5-FU may enhance the antitumor effects of LCA, and further studies on the antitumor activity of LCA anti-tumor activity in vivo are required.

\section{Acknowledgements}

This study was supported by The National Natural Science Foundation of China (grant no. 81101648). The authors acknowledge American Journal Experts for the English language editing revision of the original manuscript.

\section{References}

1. Bang YJ, Van Cutsem E, Feyereislova A, Chung HC, Shen L, Sawaki A, Lordick F, Ohtsu A, Omuro Y, Satoh T, et al: Trastuzumab in combination with chemotherapy versus chemotherapy alone for treatment of HER2-positive advanced gastric or gastro-oesophageal junction cancer (ToGA): A phase 3 , open-label, randomised controlled trial. Lancet 376: 687-697, 2010.

2. Kamangar F, Dores GM, Anderson WF. Patterns of cancer incidence, mortality, and prevalence across five continents: Defining priorities to reduce cancer disparities in different geographic regions of the world. J Clin Oncol 24: 2137-2150, 2006.

3. Zare A, Mahmoodi M, Mohammad K, Zeraati H, Hosseini M and Holakouie Naieni K: Factors affecting the survival of patients with gastric cancer undergone surgery at iran cancer institute: Univariate and multivariate analyses. Iran J Public Health 43: 800-808, 2014.

4. Schwartz GK, Winter K, Minsky BD, Crane C, Thomson PJ, Anne P, Gross H, Willett C and Kelsen D: Randomized phase II trial evaluating two paclitaxel and cisplatin-containing chemoradiation regimens as adjuvant therapy in resected gastric cancer (RTOG-0114). J Clin Oncol 27: 1956-1962, 2009.

5. Zan X, Cui F, Li Y, Yang Y, Wu D, Sun W and Ping L: Hericium erinaceus polysaccharide-protein HEG-5 inhibits SGC-7901 cell growth via cell cycle arrest and apoptosis. Int J Biol Macromol 76: 242-253, 2015.

6. Rasul A, Yu B, Khan M, Zhang K, Iqbal F, Ma T and Yang H: Magnolol, a natural compound, induces apoptosis of SGC-7901 human gastric adenocarcinoma cells via the mitochondrial and PI3K/Akt signaling pathways. Int J Oncol 40: 1153-1161, 2012.

7. Lee Y: Induction of apoptosis by S-allylmercapto-L-cysteine, a biotransformed garlic derivative, on a human gastric cancer cell line. Int J Mol Med 21: 765-770, 2008.

8. Ma K, Liu Y, Zhu Q, Liu CH, Duan JL, Tan BK and Zhu YZ: H2S donor, S-propargyl-cysteine, increases CSE in SGC-7901 and cancer-induced mice: Evidence for a novel anti-cancer effect of endogenous H2S? PLoS One 6: e20525, 2011.

9. Ma J, Liu C, Chen Y, Jiang J and Qin Z: Cellular and molecular mechanisms of the Ganoderma applanatum extracts induces apoptosis on SGC-7901 gastric cancer cells. Cell Biochem Funct 29: 175-182, 2011.

10. Cuendet M, Guo J, Luo Y, Chen S, Oteham CP, Moon RC, van Breemen RB, Marler LE and Pezzuto JM: Cancer chemopreventive activity and metabolism of isoliquiritigenin, a compound found in licorice. Cancer Prev Res (Phila) 3: 221-232, 2010.

11. Tamir S, Eizenberg M, Somjen D, Stern N, Shelach R, Kaye A and Vaya J: Estrogenic and antiproliferative properties of glabridin from licorice in human breast cancer cells. Cancer Res 60: 5704-5709, 2000.

12. Kim YH, Shin EK, Kim DH, Lee HH, Park JH and Kim JK: Antiangiogenic effect of licochalcone A. Biochem Pharmacol 80: $1152-1159,2010$.
13. Lee CK, Son SH, Park KK, Park JH, Lim SS, Kim SH and Chung WY: Licochalcone A inhibits the growth of colon carcinoma and attenuates cisplatin-induced toxicity without a loss of chemotherapeutic efficacy in mice. Basic Clin Pharmacol Toxicol 103: 48-54, 2008.

14. Yo YT, Shieh GS, Hsu KF, Wu CL and Shiau AL: Licorice and licochalcone-A induce autophagy in $\mathrm{LNCaP}$ prostate cancer cells by suppression of $\mathrm{Bcl}-2$ expression and the mTOR pathway. J Agric Food Chem 57: 8266-8273, 2009.

15. Xiao XY, Hao M, Yang XY, Ba Q, Li M, Ni SJ, Wang LS and Du X: Licochalcone A inhibits growth of gastric cancer cells by arresting cell cycle progression and inducing apoptosis. Cancer Lett 302: 69-75, 2011.

16. Takeyoshi I, Makita F, Tanahashi Y, Iwazaki S, Ogawa T, Tomizawa N, Nakamura S, Ishikawa H, Ohya T, Kakinuma S, et al: A Phase II Study of Weekly Paclitaxel and doxifluridine combination chemotherapy for advanced/recurrent gastric cancer. Anticancer Res 31: 287-291, 2011.

17. Cai XZ, Huang WY, Qiao Y, Du SY, Chen Y, Chen D, Yu S, Che RC, Liu N and Jiang Y: Inhibitory effects of curcumin on gastric cancer cells: A proteomic study of molecular targets. Phytomedicine 20: 495-505, 2013.

18. Ye YW, Hu S, Shi YQ, Zhang XF, Zhou Y, Zhao CL, Wang GJ, Wen JG and Zong H: Combination of the FGFR4 inhibitor PD173074 and 5-fluorouracil reduces proliferation and promotes apoptosis in gastric cancer. Oncol Rep 30: 2777-2784, 2013.

19. Liang X, Tang J, Liang Y, Jin R and Cai X: Suppression of autophagy by chloroquine sensitizes 5-fluorouracil-mediated cell death in gallbladder carcinoma cells. Cell Biosci 4: 10, 2014.

20. Jiang CP, Wu BH, Wang BQ, Fu MY, Yang M, Zhou Y and Liu F: Overexpression of ECRG4 enhances chemosensitivity to 5-fluorouracil in the human gastric cancer SGC-7901 cell line. Tumour Biol 34: 2269-2273, 2013 .

21. Adams JM and Cory S: The Bcl-2 protein family: Arbiters of cell survival. Science 281: 1322-1326, 1998.

22. Fan Y, Liu C, Huang Y,Zhang J, Cai L, Wang S, Zhang Y, Duan X and Yin Z: Dipyrithione induces cell-cycle arrest and apoptosis in four cancer cell lines in vitro and inhibits tumor growth in a mouse model. BMC Pharmacol Toxicol 14: 54, 2013.

23. Fu Z, Ren L, Wei H, Lv J, Che X, Zhu Z, Jia J, Wang L, Lin G, $\mathrm{Lu} \mathrm{R}$ and Yao Z: Effects of Tyroserleutide on phosphatidylinositol 3'-kinase/AKT pathway in human hepatocellular carcinoma cell. J Drug Target 22: 146-155, 2014.

24. As MN and Hosseinzadeh $\mathrm{H}$ : Review of pharmacological effects of Glycyrrhiza sp. and its bioactive compounds. Phytother Res 22: 709-724, 2008.

25. Cho JJ, Chae JI, Yoon G, Kim KH, Cho JH, Cho SS, Cho YS and Shim JH: Licochalcone A, a natural chalconoid isolated from Glycyrrhiza inflata root, induces apoptosis via Sp1 and Sp1 regulatory proteins in oral squamous cell carcinoma. Int J Oncol 45: 667-674, 2014.

26. Schuhmacher C, Gretschel S, Lordick F, Reichardt P, Hohenberger W, Eisenberger CF, Haag C, Mauer ME, Hasan B, Welch J, et al: Neoadjuvant chemotherapy compared with surgery alone for locally advanced cancer of the stomach and cardia: European organisation for research and treatment of cancer randomized trial 40954. J Clin Oncol 28: 5210-5218, 2010.

27. Wagner AD, Grothe W, Haerting J, Kleber G, Grothey A and Fleig WE: Chemotherapy in advanced gastric cancer: A systematic review and meta-analysis based on aggregate data. J Clin Oncol 24: 2903-2909, 2006.

28. Hallett RM, Huang C, Motazedian A, Auf der Mauer S, Pond GR, Hassell JA, Nordon RE and Draper JS: Treatment-induced cell cycle kinetics dictate tumor response to chemotherapy. Oncotarget 6: 7040-7052, 2015.

29. Malumbres M: Cyclin-dependent kinases. Genome Biol 15: 122, 2014.

30. Yadav V, Sultana S, Yadav J and Saini N: Gatifloxacin induces $\mathrm{S}$ and G2-phase cell cycle arrest in pancreatic cancer cells via p21/p27/p53. PLoS One 7: e47796, 2012.

31. Lin HP, Lin CY, Huo C, Hsiao PH, Su LC, Jiang SS, Chan TM, Chang $\mathrm{CH}$, Chen LT, Kung HJ, et al: Caffeic acid phenethyl ester induced cell cycle arrest and growth inhibition in androgen-independent prostate cancer cells via regulation of Skp2, p53, p21Cip1 and p27Kip1. Oncotarget 6: 6684-6707, 2015.

32. Datto MB, Li Y, Panus JF, Howe DJ, Xiong Y and Wang XF: Transforming growth factor beta induces the cyclin-dependent kinase inhibitor p21 through a p53-independent mechanism. Proc Natl Acad Sci USA 92: 5545-5549, 1995. 
33. Asghar U, Witkiewicz AK, Turner NC and Knudsen ES: The history and future of targeting cyclin-dependent kinases in cancer therapy. Nat Rev Drug Discov 14: 130-146, 2015.

34. Park MT and Lee SJ: Cell Cycle and Cancer. J Biochem Mol Biol 36: 60-65, 2003.

35. Nag S, Zhang X, Srivenugopal KS, Wang MH, Wang W and Zhang R: Targeting MDM2-p53 interaction for cancer therapy: Are we there Yet? Curr Med Chem 21: 553-574, 2014.

36. Adams JM and Cory S: The Bcl-2 apoptotic switch in cancer development and therapy. Oncogene 26: 1324-1337, 2007.

37. Zimmermann KC, Bonzon C and Green DR: The machinery of programmed cell death. Pharmacol Ther 92: 57-70, 2001.
38. Jo EH, Kim SH, Ra JC, Kim SR, Cho SD, Jung JW, Yang SR, Park JS, Hwang JW, Aruoma OI, et al: Chemopreventive properties of the ethanol extract of chinese licorice (Glycyrrhizauralensis) root: Induction of apoptosis and G1 cell cycle arrest in MCF-7 human breast cancer cells. Cancer Lett 230: 239-247, 2005. 